\title{
The role of lasers and intense pulsed light technology in dermatology
}

This article was published in the following Dove Press journal:

Clinical, Cosmetic and Investigational Dermatology

4 February 2016

Number of times this article has been viewed

\author{
Zain Husain' \\ Tina S Alster ${ }^{1,2}$ \\ 'Department of Dermatology, \\ Georgetown University Hospital, \\ ${ }^{2}$ Washington Institute of \\ Dermatologic Laser Surgery, \\ Washington, DC, USA
}

Correspondence: Tina S Alster Washington Institute of Dermatologic Laser Surgery 1430 K Street NW, Suite 200 Washington, DC 20005, USA

$\mathrm{Tel}+\mathrm{I} 2026288855$

Fax +I 2026288850

Email talster@skinlaser.com
Abstract: The role of light-based technologies in dermatology has expanded dramatically in recent years. Lasers and intense pulsed light have been used to safely and effectively treat a diverse array of cutaneous conditions, including vascular and pigmented lesions, tattoos, scars, and undesired hair, while also providing extensive therapeutic options for cosmetic rejuvenation and other dermatologic conditions. Dermatologic laser procedures are becoming increasingly popular worldwide, and demand for them has fueled new innovations and clinical applications. These systems continue to evolve and provide enhanced therapeutic outcomes with improved safety profiles. This review highlights the important roles and varied clinical applications that lasers and intense pulsed light play in the dermatologic practice.

Keywords: laser, intense pulsed light, treatment, dermatology, technology

\section{Laser and intense pulsed light principles}

Laser is an acronym, which represents light amplification by the stimulated emission of radiation. An understanding of the fundamental properties of laser light is essential to appreciate its clinical effects on the skin. ${ }^{1,2}$ First, laser light is monochromatic, meaning that the emitted light is composed of a single wavelength. This is determined by the medium of the laser system through which the light passes. Second, laser light is coherent - traveling in phase spatially and temporally. Third, laser light is collimated emitted in a parallel manner with minimal divergence.

Laser light may be absorbed, reflected, transmitted, or scattered when applied to the skin. In order for a clinical effect to occur, light must be absorbed by tissue. Absorption of laser light is determined by chromophores - the target molecules found in the skin, which have specific wavelength absorption profiles. The three primary endogenous cutaneous chromophores are water, melanin, and hemoglobin; whereas tattoo ink represents an exogenous chromophore. Upon absorption of laser energy by the skin, photothermal, photochemical, or photomechanical effects may occur. The cutaneous depth of penetration of laser energy is dependent upon absorption and scattering. In the epidermis, there is minimal light scattering, whereas in the dermis there is significant scatter due to the high concentration of collagen fibers. The amount of scattering of laser energy is inversely proportional to the wavelength of light. The depth of laser energy increases with wavelength until the mid-infrared region of the electromagnetic spectrum, at which point dermal penetration becomes more superficial due to increased absorption within tissue water.

The theory of selective photothermolysis proposed by Anderson and Parrish ${ }^{3}$ in 1983 has been pivotal in the advancement of laser surgery. It explains the mechanism 
by which controlled destruction of a cutaneous target can be achieved without significant injury to surrounding tissue. Three principles are crucial to the process. First, an appropriate wavelength should be employed that can be absorbed preferentially by the targeted tissue chromophore. Second, the pulse duration of the laser must be shorter than the chromophore's thermal relaxation time, which is the time required for the target to lose half of its peak temperature following irradiation. Third, the fluence (or energy) must be sufficient to achieve destruction of the target within the appropriate time interval. These factors guide the selection of lasers and intense pulsed light (IPL) appropriate for a specific skin target or lesion.

Lasers can be further classified by their mode of light emission. Continuous wave $(\mathrm{CW})$ lasers produce a continuous beam of light with long exposure durations that can cause nonselective tissue damage. Quasi-CW mode produces interrupted emissions of constant laser energy by shuttering the $\mathrm{CW}$ beam into short intervals. Pulsed laser systems emit high-energy laser light in ultrashort pulse durations with relatively long interpulse time intervals. They can be long pulsed (LP) or very short pulsed such as the quality-switched (QS) nanosecond and picosecond laser systems.

IPL is a nonlaser filtered flash lamp device. Unlike lasers, IPL devices emit polychromatic, noncoherent, and noncollimated light (420-1,400 nm) with varying pulse durations. The wider range of light can be absorbed by a variety of chromophores, making IPL less selective than lasers. As such, cutoff filters are often used to narrow the spectrum of emitted wavelengths and render the device more specific.

\section{Treatment of vascular lesions}

Vascular lesions are frequently treated with lasers and IPL due to the systems' ability to specifically target intravascular oxyhemoglobin. This endogenous chromophore has three primary absorption peaks within the visible light spectrum: 418, 542, and $577 \mathrm{~nm}$. Oxyhemoglobin absorbs the laser light, which is subsequently converted to heat and transferred to the vessel wall causing coagulation and vessel closure. Treatment with vascular-specific lasers causes inhomogeneous heating within dermal blood vessels due to their varying sizes, but results in effective and efficient treatment of small- and large-diameter blood vessels. ${ }^{4}$ Historically, multiple laser systems were shown to be effective in the treatment of vascular lesions, but several fell out of favor due to high rates of adverse effects. The most commonly used vascular lasers in current clinical practice are the potassium titanyl phosphate (KTP, $532 \mathrm{~nm})$, pulsed dye laser (PDL, 585-595 nm), alexandrite (755 nm), diode (800-810, $940 \mathrm{~nm}$ ), and neodymium-doped yttrium aluminum garnet (Nd:YAG, 532 and 1,064 nm). In addition, IPL with appropriate filters can be used to treat certain vascular lesions. ${ }^{5}$

The KTP laser is effective in the treatment of numerous superficial vascular lesions, particularly facial telangiectasias. ${ }^{6,7}$ Treatments are well tolerated and adverse effects include erythema, edema, and crusting. One of the advantages of the KTP laser is that postoperative purpura and erythema are minimized. Its shorter wavelength results in decreased tissue penetration and limited absorption by hemoglobin in deeper vessels. Given that there is considerable absorption of $532 \mathrm{~nm}$ energy by melanin, caution must be exercised when treating patients with darker skin.

The PDL is a highly effective laser for the treatment of a wide range of vascular lesions and is considered the workhorse vascular laser in many practices due to its favorable clinical efficacy and low risk profile. The PDL has successfully been used to treat port-wine stains, ${ }^{8-17}$ facial telangiectasias, ${ }^{18-20}$ hemangiomas, ${ }^{21-25}$ pyogenic granulomas, ${ }^{26}$ Kaposi's sarcoma, ${ }^{27}$ and poikiloderma of Civatte. ${ }^{28}$ In addition, PDL is highly effective in the treatment of hypertrophic and keloid scars, ${ }^{29-31}$ striae distensae, ${ }^{32,33}$ verrucae, ${ }^{34,35}$ angiofibromas, ${ }^{36}$ lymphangiomas, and many other dermatologic conditions. ${ }^{37-49}$ Fluences ranging $5-10 \mathrm{~J} / \mathrm{cm}^{2}$ using 3-10 $\mathrm{mm}$ spot sizes with a minimal to no pulse overlap reduces unwanted thermal injury. Adverse effects include postoperative purpura, transient dyspigmentation, and rarely vesiculation, crusting, and scarring. Newer PDLs with longer wavelengths and extended pulse durations have enabled deeper tissue penetration and improved clinical outcomes (Figure 1A and B).

IPL has also been used to effectively treat a variety of vascular lesions, including facial telangiectasias, capillary malformations, poikiloderma of Civatte, venous malformations, and infantile hemangiomas. ${ }^{5,50-52}$ Its noncoherent light emits wavelengths ranging from 420 to $1,400 \mathrm{~nm}$. Filters are used to limit the wavelengths emitted by the device in order to improve dermal penetration and minimize absorption of energy by other chromophores. IPL energy is delivered as a series of single, double, or triple pulse sequences with pulse durations of 2-25 milliseconds and interpulse delays of 10-500 milliseconds. Longer pulse durations are used to more effectively heat deeper vessels, thereby reducing the risk of purpura and hyperpigmentation.

Prominent leg veins are a common cosmetic concern and can be challenging to treat. Sclerotherapy is highly 
A

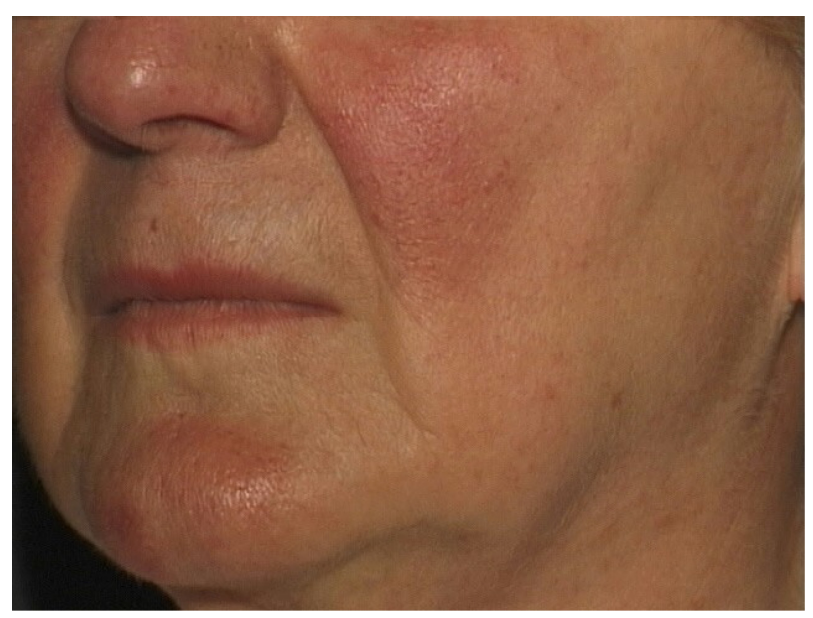

B

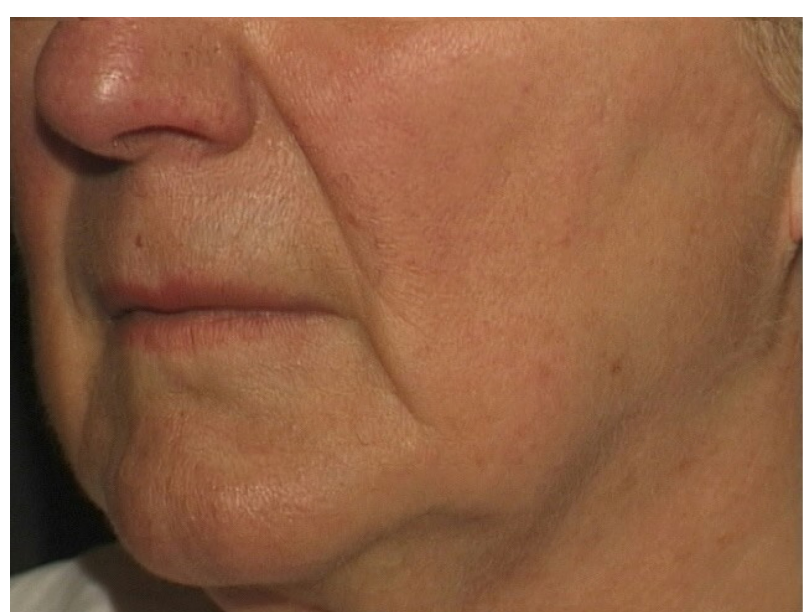

Figure I Facial erythema and prominent telangiectasias in a patient with rosacea before (A) and after two $595 \mathrm{~nm}$ pulsed dye laser (PDL) treatments (B).

effective for leg veins and is considered the gold standard treatment; however, it can be associated with significant adverse effects such as ulceration, allergic reactions, and telangiectatic matting. ${ }^{53,54}$ The KTP and PDL lasers as well as IPL have shown efficacy in the treatment of small vessels measuring $<1 \mathrm{~mm} .{ }^{55-57}$ The treatment of larger and/or deeper vessels requires longer wavelengths and pulse durations. The LP alexandrite $(755 \mathrm{~nm})$, diode $(800 \mathrm{~nm})$, and Nd:YAG $(1,064 \mathrm{~nm})$ lasers have each been successful in eradicating small- to medium-sized veins. ${ }^{57-59}$

\section{Treatment of hypertrophic scars, keloids, and striae}

Hypertrophic scars and keloids are abnormal wound responses to cutaneous injury and are marked by excessive collagen formation. They are difficult to treat and have high recurrence rates following conventional treatments such as surgical excision, dermabrasion, radiation, and intralesional therapy. ${ }^{60-62}$ Many studies have been published in which scars treated with PDL resulted in improvement in erythema, texture, pliability, and pain, with minimal side effects. ${ }^{29-31,63}$ Significant clinical improvement of hypertrophic scars is often observed after one or two PDL treatments, with greatest responses observed with the use of lower energy densities ${ }^{64}$ (Figure 2A and B). Adjunctive therapies to PDL such as intralesional corticosteroids or 5-fluorouracil are most useful for resistant keloids and/or actively proliferating hypertrophic scars. ${ }^{65,66}$ Adverse effects after PDL treatment are mild and include purpura that typically dissipates in several days and temporary dyspigmentation that resolves spontaneously over time. More recently, ablative fractional lasers have been shown to improve hypertrophic scars and are often combined with topical delivery of corticosteroids for improved efficacy. ${ }^{67,68}$

Striae distensae are common atrophic lesions that are often associated with obesity, pregnancy, puberty, and exogenous steroid use. They initially present as slightly erythematous to pink atrophic bands, termed striae rubra. They gradually become hypopigmented and fibrotic and are referred to as striae alba. Striae have been treated successfully with low-fluence PDL, with stria rubra showing greater clinical response to treatment than mature striae alba. ${ }^{32,63}$ Fractional ablative and nonablative lasers have also been shown to improve the pigmentation and texture of striae distensae. ${ }^{69,70}$

\section{Treatment of pigmented lesions}

Cutaneous pigmented lesions are frequent targets of laser and IPL treatment. QS lasers are highly effective in lightening or eliminating benign epidermal and dermal pigmented lesions such as solar lentigines, ephelides, café au lait macules, seborrheic keratoses, melanocytic nevi, blue nevi, nevi of Ota/Ito, infraorbital hyperpigmentation, druginduced hyperpigmentation, Becker's nevi, and nevi spilus. These same lasers have also been used to treat amateur, professional, and traumatic tattoos. The red and infrared wavelengths of the QS lasers target melanin within melanosomes (as is the case with pigmented lesions) and various carbon-based material or organometallic dyes (as is the case with tattoos), with limited injury to adjacent normal tissue. ${ }^{71}$ A variety of different lasers (including $\mathrm{CW}$ and quasi-CW systems) have been used to treat pigmented lesions in the past; however, they are not currently in wide use due to significant risk of scarring and dyspigmentation. ${ }^{72-74}$ The short pulsed QS and picosecond systems commonly used to treat pigmented lesions and tattoos today include 
A

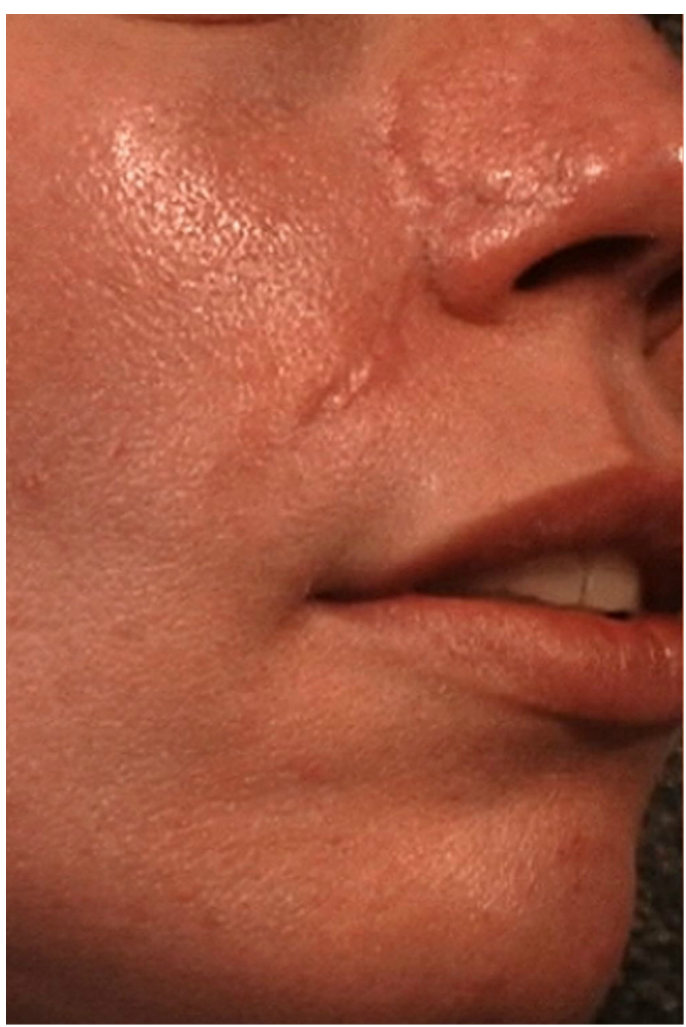

B

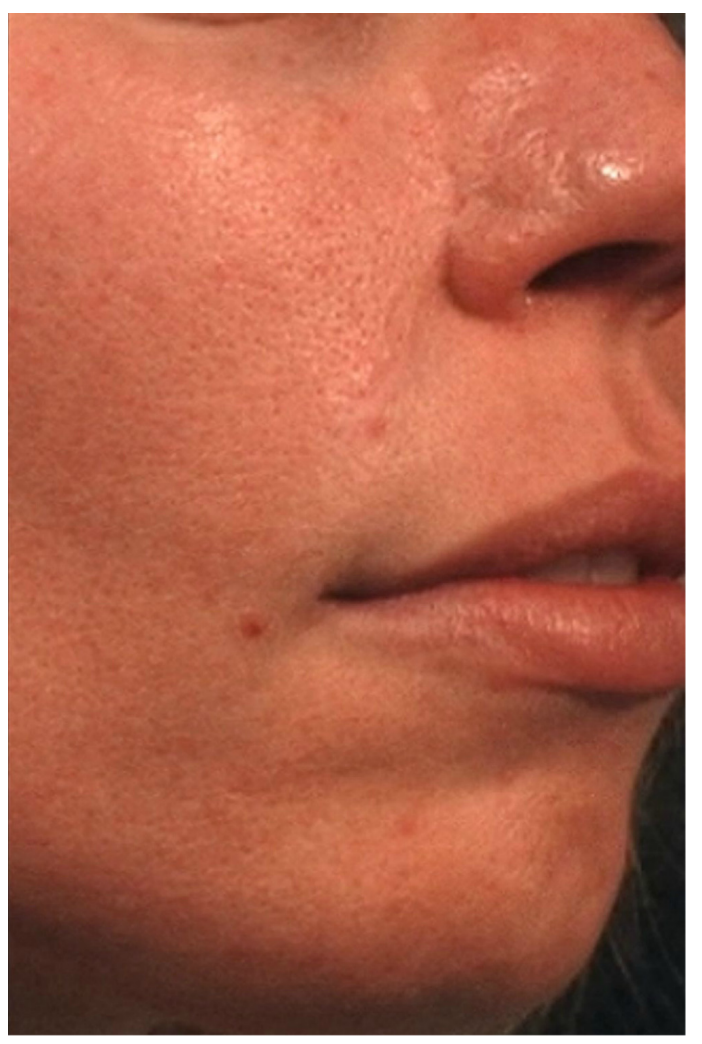

Figure 2 Hypertrophic and erythematous surgical scar before $(\mathbf{A})$ and after two pulsed dye laser (PDL) treatments (B).

Note: Reprinted from Facial Plast Surg Clin North Am, 20 I I; 19(3), Sobanko JF, Alster TS, Laser treatment for improvement and minimization of facial scars, 527-542, ${ }^{61}$ Copyright $@ 2011$, with permission from Elsevier.
Nd:YAG (532 and 1,064 $\mathrm{nm})$, ruby (694 nm), and alexandrite $(755 \mathrm{~nm})$ lasers.

The QS ruby was the first system developed to treat pigmented lesions and tattoos and was widely and successfully used; ${ }^{75-82}$ however, its $694 \mathrm{~nm}$ wavelength required caution in patients with darker skin tones due to its energy being so strongly absorbed by melanin with a greater risk of hypopigmentation. ${ }^{83,84}$ The subsequent development of QS alexandrite and Nd:YAG lasers were also shown to effectively treat pigmented lesions and tattoos with the advantage that their longer wavelengths could safely treat darker skin and penetrate into the deeper dermis. ${ }^{85-100}$ Most recently, Q-switched lasers that generate picosecond domain pulses have been commercially introduced with an even greater ability to target and destroy cutaneous pigment and ink ${ }^{101}$ (Figure $3 \mathrm{~A}$ and $\mathrm{B}$ ).

Effective tattoo removal necessitates the use of an appropriate wavelength that is preferentially absorbed by the specific ink color within the tattoo. ${ }^{102}$ Black pigment absorbs wavelengths from red through the infrared spectrum

A

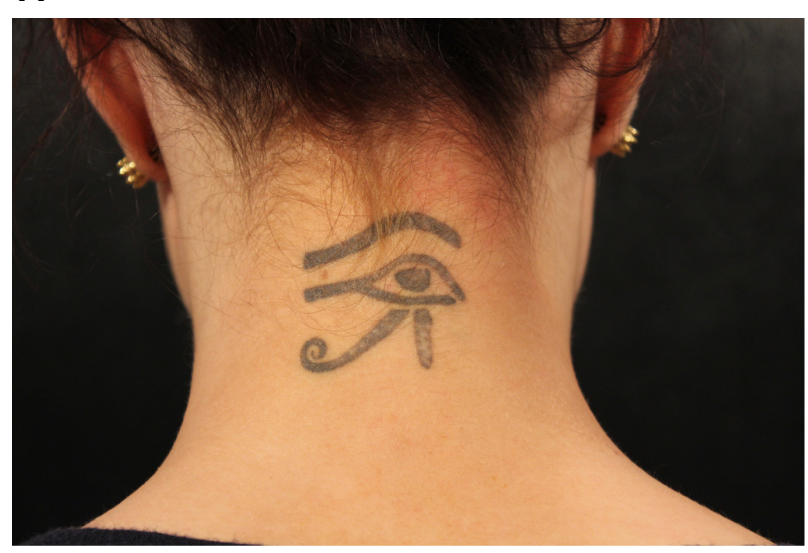

B

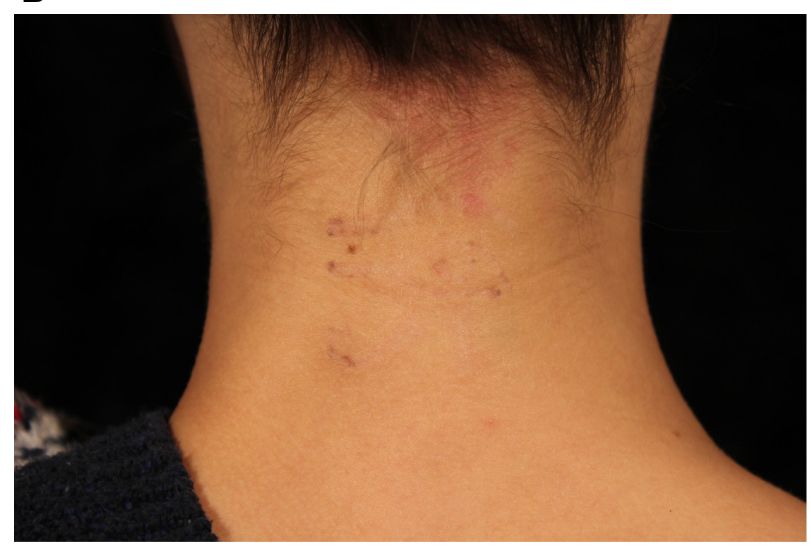

Figure 3 Professional tattoo before $(\mathbf{A})$ and after third picosecond $\mathrm{Nd}$ :YAG laser treatment (B). 
and can thus be treated with QS ruby, QS alexandrite, or QS Nd:YAG lasers. The QS ruby or alexandrite lasers can safely target blue and green inks since these pigments absorb in the 600-800 nm range, whereas only the $532 \mathrm{~nm}$ QS Nd:YAG laser can clear red, orange, and yellow inks. Cosmetic tattoo inks that are typically tan, white, or rust colored are difficult to treat because they frequently contain iron oxide and titanium dioxide compounds that undergo a chemical reaction upon laser irradiation to a black and insoluble form (ferric oxide to ferrous oxide). ${ }^{103}$ Professional tattoos are more difficult and require additional sessions to eliminate than amateur tattoos, given the dense dermal concentration of ink in the former. Adverse effects of laser tattoo removal include transient pigmentary alteration (hypo- and hyperpigmentation), systemic allergic or localized granulomatous tissue reactions, ignition of explosive particles in traumatic tattoos, and atrophic scars. ${ }^{104,105}$

IPL devices have also been used to treat benign pigmented lesions including ephelides and solar lentigines, with significant lesional improvement observed after a series of monthly treatments. ${ }^{106-108}$ They are relatively ineffective in the treatment of tattoos because of their inability to deliver short pulses that can target and pulverize ink particles.

\section{Hair removal}

Safe and long-lasting hair reduction in cosmetically undesirable locations can be achieved with a variety of lasers and IPL devices. These systems emit red and infrared light with wavelengths ranging 600-1,200 nm, which are capable of targeting melanin in the hair shaft, follicular epithelium, and hair matrix. ${ }^{109-111}$ Since melanin is also normally present in the epidermis, it presents as another competing source for laser energy absorption and can lead to undesirable epidermal damage. Concomitant epidermal cooling sources help to minimize unwanted thermal injury (particularly in patients with darker skin) during treatment. While pulse durations of 10-100 milliseconds are typically used (in keeping with the thermal relaxation time of most hair follicles), the biological target in laser hair removal is the follicular stem cell, which is located in the bulge region or dermal papilla of the hair follicle. Since these stem cells do not always contain significant amounts of melanin and may not be directly adjacent to the targeted pigmented structures, longer pulse durations than those outlined are often necessary for heat diffusion from the follicular shaft to the desired end-target. ${ }^{112}$ Permanent hair reduction without significant adverse effects has been achieved despite the use of prolonged pulse durations. ${ }^{113}$
LP ruby (694 nm), alexandrite $(755 \mathrm{~nm})$, diode $(800 \mathrm{~nm})$, and Nd:YAG $(1,064 \mathrm{~nm})$ lasers as well as IPL (590-1,200 $\mathrm{nm}$ ) have been shown, through numerous published studies, to achieve long-lasting hair reduction with a low incidence of adverse effects. ${ }^{110,114-128}$ The optimal laser or IPL selection is determined by the patient's skin type. The LP ruby laser is best used in pale-skinned patients with Fitzpatrick skin phototypes I-III, ${ }^{114}$ whereas the LP alexandrite and diode lasers can be safely used in individuals with slightly darker skin (Fitzpatrick skin phototypes I-IV). The LP Nd:YAG laser system is considered the safest option for darker skinned patients due to the decreased risk of epidermal injury by its longer wavelength. ${ }^{129}$ Using specific cutoff filters, the IPL system can also be used for hair reduction in patients with paler skin. While significant hair reduction can be seen after one treatment, multiple treatment sessions at monthly time intervals improves the clinical outcome. ${ }^{125,126}$ Adverse effects after laser or IPL treatments include blistering, crusting, dyspigmentation, and rarely scarring. It is important to select the appropriate laser system with correct treatment parameters and caution should be exercised in patients with tans or intrinsically dark skin.

\section{Ablative laser resurfacing}

Laser skin resurfacing has evolved significantly over the past 2 decades. It was first popularized in the mid-1990s following the introduction of the pulsed carbon dioxide $\left(\mathrm{CO}_{2}\right)$ laser system for the treatment of facial rhytides and atrophic acne scars. ${ }^{130}$ The $10,600 \mathrm{~nm}$ wavelength emitted by a $\mathrm{CO}_{2}$ laser is absorbed by intracellular water, resulting in tissue heating and vaporization. The pulsed $\mathrm{CO}_{2}$ laser produces discrete areas of tissue vaporization while minimizing thermal injury to surrounding tissue that can be associated with scarring and hypopigmentation. Subsequent to the development of the pulsed and scanned $\mathrm{CO}_{2}$ laser systems, the erbium-doped yttrium aluminum garnet (Er:YAG) laser was introduced. Its 2,940 $\mathrm{nm}$ wavelength also resulted in controlled skin ablation with minimal thermal injury. Because the Er:YAG system creates little thermal reaction in the skin, tissue tightening is not as dramatic as that seen after $\mathrm{CO}_{2}$ laser treatment. On the other hand, the minimal thermal injury created by Er:YAG laser irradiation leads to quicker postoperative healing and fewer side effects.

While numerous cosmetic applications of pulsed and scanned $\mathrm{CO}_{2}$ and Er:YAG ablative lasers have been reported, they have been most frequently used for facial rejuvenation of photodamaged skin, including rhytides and dyschromia. ${ }^{131-138}$ 
Atrophic acne and traumatic scars also can be effectively treated with ablative lasers. ${ }^{139,140}$ Impressive skin tightening has been demonstrated with $\mathrm{CO}_{2}$ laser skin resurfacing due to the thermal effect on dermal collagen. ${ }^{141,142}$ Ablative lasers have been successfully used to treat verrucae vulgaris, seborrheic keratosis, syringoma, xanthelasma, onychodystrophy, actinic keratosis, and Zoon's balanitis among other dermatologic conditions. ${ }^{143-145}$

While extremely effective, prolonged side effects and complications associated with ablative laser resurfacing were reported. ${ }^{146-150}$ Frequently encountered posttreatment reactions include intense erythema and edema, which can persist for several weeks to months. ${ }^{148}$ Milia and acne can be experienced, particularly in individuals with a previous history of acne and in treatment of scars. ${ }^{147}$ Infections are relatively uncommon, but patients with a history of herpes labialis should receive prophylactic oral antiviral therapy to reduce the incidence of latent herpes reactivation. ${ }^{151,152}$ Postinflammatory hyperpigmentation occurs not infrequently, particularly in patients with darker skin tones or after aggressive laser treatment. ${ }^{153}$ Delayed hypopigmentation is far less common - typically observed several months ( $>6$ months) after treatment ${ }^{147}$ and develops more frequently with $\mathrm{CO}_{2}$ laser ablation than with Er:YAG. Hypertrophic scarring is another infrequent complication that can result from aggressive laser technique, infection, and poor wound management. Rarely seen is ectropion formation, which can occur when lax periocular skin is vaporized in patients with a previous history of lower blepharoplasty.

\section{Nonablative laser resurfacing}

Nonablative laser systems were developed primarily to reduce the risk of adverse effects and the extensive postoperative recovery period associated with ablative laser resurfacing. There are several nonablative laser and IPL devices, most of which emit infrared light. They include the Nd:YAG (1,064 and 1,320 nm), diode (980 and 1,450 nm), erbium: glass (Er:glass, 1,540 nm), and IPL (500-1,200 nm) systems. Similar to ablative lasers, they primarily target dermal water, which causes collagen heating and dermal remodeling. Unlike their ablative counterparts; however, epidermal injury and tissue vaporization does not occur due to the concomitant application of epidermal cooling. Clinical applications of nonablative lasers include facial and nonfacial rhytides and scars. ${ }^{154-157}$ Treatments are typically performed in a series of three or more monthly sessions to achieve optimal clinical results. ${ }^{154-157}$ Because the epidermis is spared from damage, nonablative lasers can be safely used on nonfacial skin and are associated with speedier recovery and lower incidence of postoperative side effects compared with ablative lasers. Posttreatment erythema and edema resolve within 24-48 hours, which is typical, but other significant side effects are rare. Blister formation is an uncommon complication stemming from insufficient epidermal cooling.

\section{Fractional laser skin resurfacing}

Fractional photothermolysis was introduced in 2004, ${ }^{158}$ thereby revolutionizing laser skin resurfacing. Fractional laser systems target tissue water and produce microscopic treatment zones of controlled width, depth, and densities in the skin. These three-dimensional thermal damage zones are referred to as "microscopic thermal zones" (MTZs) and are the fundamental units of fractional photothermolysis. In contrast to full-field resurfacing, only a fraction of the skin is removed. The energy in the fractionated columns of the laser induces thermal damage without affecting neighboring tissue. Adjacent unaffected tissue serves as a source for healing and rapid epidermal repair via migration. The targeted damage with MTZ stimulates neocollagenosis and collagen remodeling. ${ }^{159,160}$ As a result, fractionated photothermolysis minimizes the risk of complications and reduces recovery times seen with the aforementioned resurfacing lasers. Fractional technology has been applied to both ablative and nonablative laser systems. Ablative fractional lasers produce MTZ of epidermal and dermal tissue vaporization, whereas nonablative fractional lasers induce epidermal and dermal coagulation without tissue vaporization.

Several nonablative fractional lasers are commercially available, including Nd:YAG $(1,440 \mathrm{~nm})$, diode (1,440 nm), erbium $(1,410,1,540$, and 1,550 $\mathrm{nm})$, and thulium $(1,927 \mathrm{~nm})$ laser systems. These lasers are frequently used for the treatment of facial and nonfacial rhytides, dyschromia, and scars. Although facial skin treatments result in superior clinical outcomes, nonfacial skin treatments are also impressive. Clinical studies have demonstrated significant improvement of facial rhytides, atrophic acne scars, hypertrophic scars, and enlarged pores when treated with various nonablative fractional lasers ${ }^{161-168}$ (Figure 4A and B). The successful treatment of melasma with nonablative lasers has been less consistent. ${ }^{169,170}$

The ablative $\mathrm{CO}_{2}$ and Er:YAG fractionated lasers are both highly effective in the treatment of photoaged skin and yield similar clinical efficacy and rapid recovery. ${ }^{171-173}$ 
A

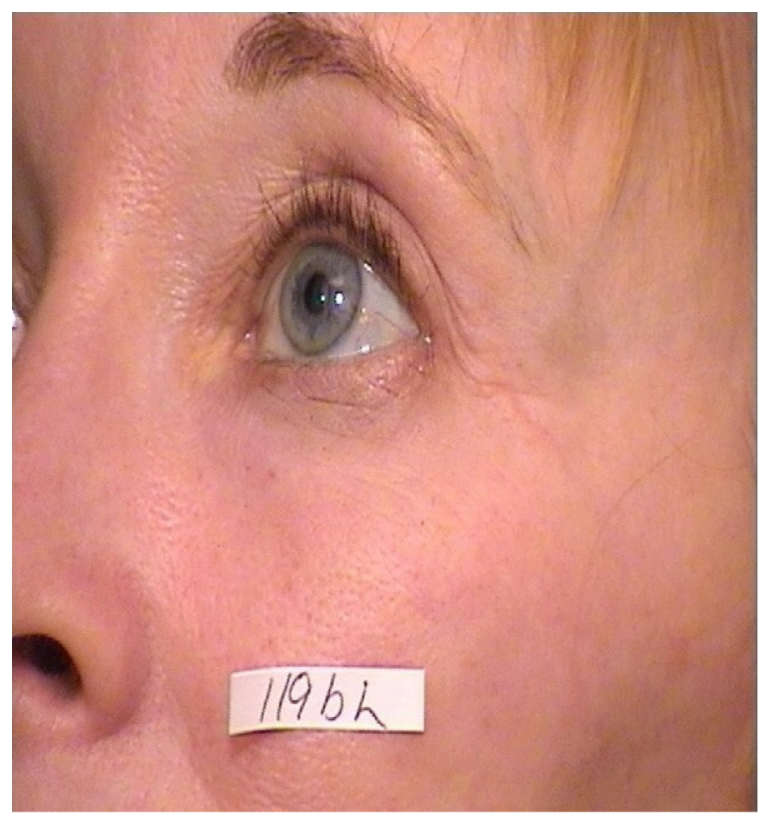

B

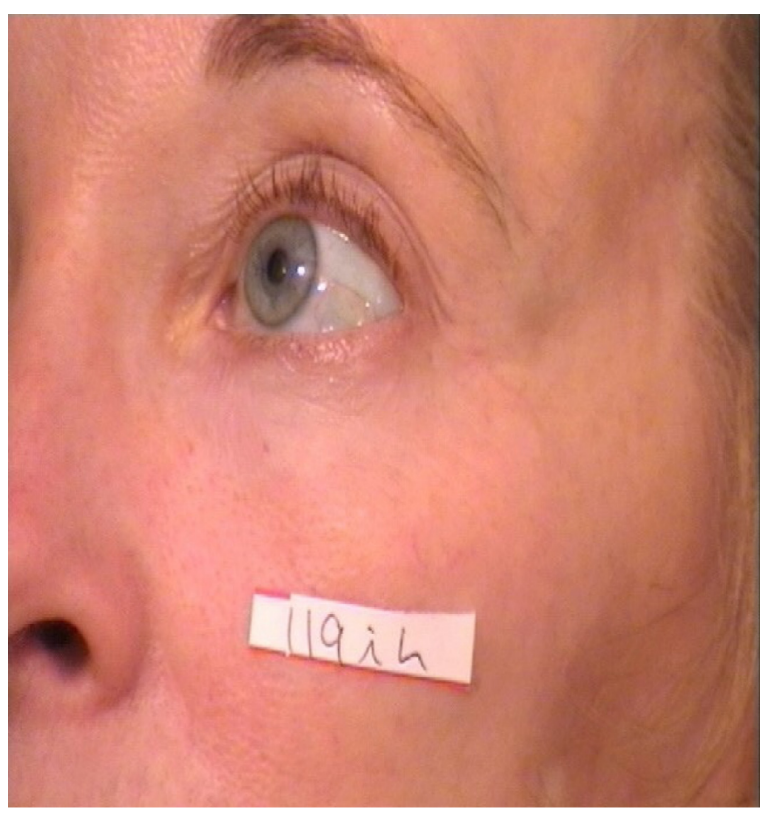

Figure 4 Periocular rhytides before $(\mathbf{A})$ and after three nonablative fractionated erbium $(1,550 \mathrm{~nm})$ laser treatments $(B)$.

Ablative fractionated lasers have also been used to successfully treat acne scars, including severe scars on a variety of anatomic locations ${ }^{174,175}$ (Figure 5A and B). Treatments are typically performed as a single procedure due to their robust clinical results compared with nonablative fractional lasers.

Although fractionated ablative and nonablative lasers have a superior safety profile compared with their nonfractionated counterparts, side effects and complications can still
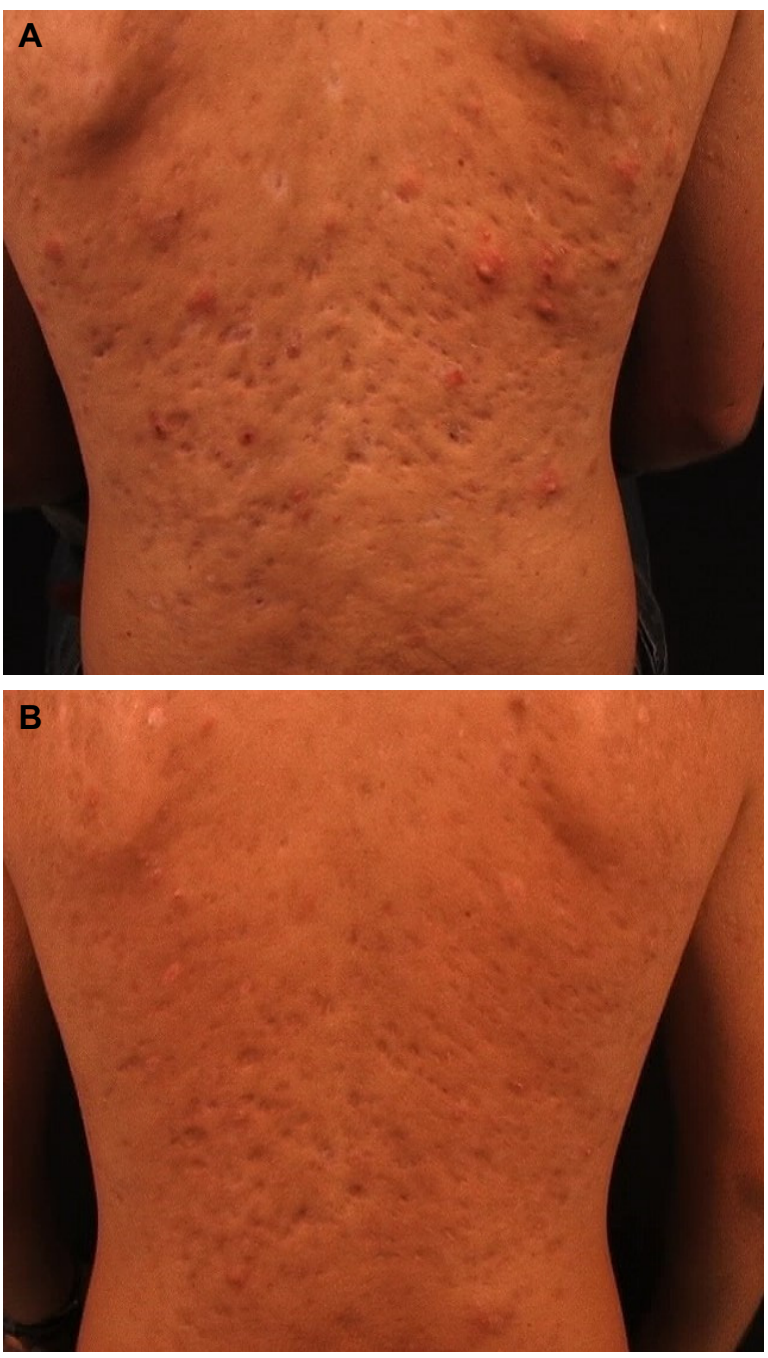

Figure 5 Severe atrophic acne scars on the back of a young man before $(\mathbf{A})$ and 6 months after one ablative fractionated carbon dioxide $\left(\mathrm{CO}_{2}\right)$ laser treatment $(\mathbf{B})$.

occur. Patients often encounter posttreatment erythema and edema following nonablative fractional resurfacing that typically resolve within 3 days. ${ }^{176}$ Erythema that extends beyond 4 days is considered prolonged and is reported in $<1 \%$ of patients. In contrast, erythema that lasts beyond 1 month following ablative fractional laser treatment is considered prolonged and is seen in $\sim 12.5 \%$ of patients. ${ }^{177}$ A $590 \mathrm{~nm}$ light-emitting diode system has been shown to reduce postfractional laser erythema. ${ }^{178}$ Herpes simplex virus infection is the most common infectious complication following fractionated laser treatment, affecting up to $2 \%$ of patients. ${ }^{177} \mathrm{It}$ is generally recommended to treat patients prophylactically if they have a history of facial herpes simplex virus or if perioral laser treatment is performed. Bacterial infection is comparatively low with an incidence of $0.1 \% .{ }^{177}$ Antibacterial prophylaxis can be useful prior to ablative fractionated laser resurfacing. In addition, transient acneiform eruptions can 
develop following fractionated laser resurfacing in up to $10 \%$ of patients, especially those with a history of acne. ${ }^{177}$ Moderate-to-severe acne flares can be treated with a short course of tetracycline-based antibiotics. Milia also develop in approximately $20 \%$ of treated patients and can be minimized by avoiding occlusive emollients. ${ }^{177}$ Postinflammatory hyperpigmentation is another possible complication, although less frequently encountered when compared with nonfractional lasers. The incidence can be $>12 \%$ in patients with darker phototypes (III-VI). ${ }^{179}$ Delayed-onset hypopigmentation, hypertrophic scarring, and the development of vertical and horizontal bands are extremely rare complications of ablative fractional resurfacing. ${ }^{180-182}$

\section{Laser phototherapy}

The effective treatment of a variety of dermatologic diseases with ultraviolet (UV) phototherapy has long been established. Psoriasis has been treated with broadband and narrowband UVB light as well as psoralen with UVA for decades with significant clinical response. The xenon chloride excimer laser $(308 \mathrm{~nm})$ has been used to treat psoriasis as well, demonstrating clearing of psoriatic plaques with fewer treatments than narrow-band UVB treatment. ${ }^{183-186}$ One of the significant advantages of the excimer laser is that it targets only affected areas of skin, thereby preventing unnecessary exposure of normal tissue to UV radiation. Numerous studies have shown the clinical efficacy of the excimer laser for the treatment of various forms of psoriasis, including a multicenter study which demonstrated that $84 \%$ of patients reached $75 \%$ improvement or better after 10 or fewer treatments. ${ }^{184}$ Treatments are often well tolerated, but adverse effects include blistering, erythema, and hyperpigmentation. Although clinically effective, treatment limitations include relative expense of therapy, time constraints when faced with large surface areas of psoriasis, and unknown risk of carcinogenesis.

The excimer laser has also been found to be as effective as narrow-band UVB in the treatment of vitiligo, with studies demonstrating greater than $75 \%$ repigmentation in patches of vitiligo after treatment. ${ }^{187}$ These significant response rates are achieved in a relatively short treatment time period compared with traditional phototherapy. ${ }^{188}$ Other conditions that have shown clinical response to the excimer laser include atopic dermatitis, alopecia areata, allergic rhinitis, folliculitis, granuloma annulare, lichen planus, mycosis fungoides, palmoplantar pustulosis, pityriasis alba, CD30+ lymphoproliferative disorder, leukoderma, prurigo nodularis, localized scleroderma, and genital lichen sclerosus. ${ }^{189}$

\section{Conclusion}

Laser and IPL systems have diverse clinical applications throughout the field of dermatology and are constantly evolving. These technologies have facilitated the treatment of benign vascular and pigmented lesions, unwanted hair, tattoos, hypertrophic scars, keloids, rhytides, as well as dermatologic diseases such as psoriasis and vitiligo. Laser resurfacing, including ablative and nonablative fractional treatments have yielded excellent cosmetic results with improved safety profiles and recovery. Refinement of existing devices and the development of novel technologies will continue to expand the role of lasers and IPL in the future and enable practitioners to deliver the most cutting-edge and sophisticated treatments for a wider range of cutaneous conditions.

\section{Disclosure}

The authors report no conflicts of interest in this work.

\section{References}

1. Tanzi EL, Lupton JR, Alster TS. Lasers in dermatology: four decades of progress. J Am Acad Dermatol. 2003;49(1):1-31; quiz 31-34.

2. Anderson RR, Parrish JA. The optics of human skin. J Invest Dermatol. 1981;77(1):13-19.

3. Anderson RR, Parrish JA. Selective photothermolysis: precise microsurgery by selective absorption of pulsed radiation. Science. 1983; 220(4596):524-527.

4. Astafyeva LG, Gade R, Schmidt WD, Ledneva GP, Wollina U, Fassler D. Laser heating of biological tissue with blood vessels: modeling and clinical trials. Opt Spectrosc. 2006;100(5):789-796.

5. Wat H, Wu DC, Rao J, Goldman MP. Application of intense pulsed light in the treatment of dermatologic disease: a systematic review. Dermatol Surg. 2014;40(4):359-377.

6. West TB, Alster TS. Comparison of the long-pulse dye (590-595 nm) and KTP $(532 \mathrm{~nm})$ lasers in the treatment of facial and leg telangiectasias. Dermatol Surg. 1998;24(2):221-226.

7. Becher GL, Cameron H, Moseley H. Treatment of superficial vascular lesions with the KTP 532-nm laser: experience with 647 patients. Lasers Med Sci. 2014;29(1):267-271.

8. Dover JS, Geronemus R, Stern RS, O’Hare D, Arndt KA. Dye laser treatment of port-wine stains: comparison of the continuous-wave dye laser with a robotized scanning device and the pulsed dye laser. $J \mathrm{Am}$ Acad Dermatol. 1995;32(2 Pt 1):237-240.

9. Tan OT, Sherwood K, Gilchrest BA. Treatment of children with portwine stains using the flashlamp-pulsed tunable dye laser. $N$ Engl J Med. 1989;320(7):416-421.

10. Alster T, Tan OT. Laser treatment of benign cutaneous vascular lesions. Am Fam Physician. 1991;44(2):547-554.

11. Alster TS, Wilson F. Treatment of port-wine stains with the flashlamppumped pulsed dye laser: extended clinical experience in children and adults. Ann Plast Surg. 1994;32(5):478-484.

12. Fitzpatrick RE, Lowe NJ, Goldman MP, Borden H, Behr KL, RuizEsparza J. Flashlamp-pumped pulsed dye laser treatment of port-wine stains. J Dermatol Surg Oncol. 1994;20(11):743-748.

13. Kauvar AN, Geronemus RG. Repetitive pulsed dye laser treatments improve persistent port-wine stains. Dermatol Surg. 1995;21(6): $515-521$.

14. Sommer S, Sheehan-Dare RA. Pulsed dye laser treatment of port-wine stains in pigmented skin. J Am Acad Dermatol. 2000;42(4):667-671. 
15. Waldorf HA, Alster TS, McMillan K, Kauvar AN, Geronemus RG, Nelson JS. Effect of dynamic cooling on 585-nm pulsed dye laser treatment of port-wine stain birthmarks. Dermatol Surg. 1997;23(8): 657-662.

16. Shi W, Wang J, Lin Y, et al. Treatment of port wine stains with pulsed dye laser: a retrospective study of 848 cases in Shandong Province, People's Republic of China. Drug Des Devel Ther. 2014;8:2531-2538.

17. Alster TS, Tanzi EL. Combined 595-nm and 1,064-nm laser irradiation of recalcitrant and hypertrophic port-wine stains in children and adults. Dermatol Surg. 2009;35(6):914-918; discussion 918-919.

18. Lowe NJ, Behr KL, Fitzpatrick R, Goldman M, Ruiz-Esparza J. Flash lamp pumped dye laser for rosacea-associated telangiectasia and erythema. J Dermatol Surg Oncol. 1991;17(6):522-525.

19. Ruiz-Esparza J, Goldman MP, Fitzpatrick RE, Lowe NJ, Behr KL. Flash lamp-pumped dye laser treatment of telangiectasia. J Dermatol Surg Oncol. 1993;19(11):1000-1003.

20. Jasim ZF, Woo WK, Handley JM. Long-pulsed (6-ms) pulsed dye laser treatment of rosacea-associated telangiectasia using subpurpuric clinical threshold. Dermatol Surg. 2004;30(1):37-40.

21. Ashinoff R, Geronemus RG. Capillary hemangiomas and treatment with the flash lamp-pumped pulsed dye laser. Arch Dermatol. 1991;127(2): 202-205.

22. Garden JM, Bakus AD, Paller AS. Treatment of cutaneous hemangiomas by the flashlamp-pumped pulsed dye laser: prospective analysis. J Pediatr. 1992;120(4 Pt 1):555-560.

23. Poetke M, Philipp C, Berlien HP. Flashlamp-pumped pulsed dye laser for hemangiomas in infancy: treatment of superficial vs mixed hemangiomas. Arch Dermatol. 2000;136(5):628-632.

24. Shen L, Zhou G, Zhao J, et al. Pulsed dye laser therapy for infantile hemangiomas: a systemic review and meta-analysis. QJM. 2015;108(6): $473-480$.

25. Kwon SH, Choi JW, Byun SY, et al. Effect of early long-pulse pulsed dye laser treatment in infantile hemangiomas. Dermatol Surg 2014;40(4):405-411.

26. Goldberg DJ, Sciales CW. Pyogenic granuloma in children. Treatment with the flashlamp-pumped pulsed dye laser. J Dermatol Surg Oncol. 1991;17(12):960-962.

27. Marchell N, Alster TS. Successful treatment of cutaneous Kaposi's sarcoma by the 585-nm pulsed dye laser. Dermatol Surg. 1997;23(10): 973-975.

28. Wheeland RG, Applebaum J. Flashlamp-pumped pulsed dye laser therapy for poikiloderma of Civatte. J Dermatol Surg Oncol. 1990; 16(1):12-16

29. Alster TS. Improvement of erythematous and hypertrophic scars by the 585-nm flashlamp-pumped pulsed dye laser. Ann Plast Surg 1994;32(2):186-190

30. Alster TS, Williams CM. Treatment of keloid sternotomy scars with $585 \mathrm{~nm}$ flashlamp-pumped pulsed-dye laser. Lancet. 1995;345(8959): 1198-1200.

31. Alster TS, Nanni CA. Pulsed dye laser treatment of hypertrophic burn scars. Plast Reconstr Surg. 1998;102(6):2190-2195.

32. McDaniel DH, Ash K, Zukowski M. Treatment of stretch marks with the 585-nm flashlamp-pumped pulsed dye laser. Dermatol Surg. 1996;22(4):332-337.

33. Jimenez GP, Flores F, Berman B, Gunja-Smith Z. Treatment of striae rubra and striae alba with the 585-nm pulsed-dye laser. Dermatol Surg. 2003;29(4):362-365

34. Tan OT, Hurwitz RM, Stafford TJ. Pulsed dye laser treatment of recalcitrant verrucae: a preliminary report. Lasers Surg Med. 1993; 13(1):127-137.

35. Kauvar AN, McDaniel DH, Geronemus RG. Pulsed dye laser treatment of warts. Arch Fam Med. 1995;4(12):1035-1040.

36. Hoffman SJ, Walsh P, Morelli JG. Treatment of angiofibroma with the pulsed tunable dye laser. J Am Acad Dermatol. 1993;29(5 Pt 1): 790-791.

37. Weingold DH, White PF, Burton CS. Treatment of lymphangioma circumscriptum with tunable dye laser. Cutis. 1990;45(5):365-366.
38. Alster TS, Wilson F. Focal dermal hypoplasia (Goltz's syndrome). Treatment of cutaneous lesions with the 585-nm flashlamp-pumped pulsed dye laser. Arch Dermatol. 1995;131(2):143-144.

39. Alster TS. Inflammatory linear verrucous epidermal nevus: successful treatment with the $585 \mathrm{~nm}$ flashlamp-pumped pulsed dye laser. $\mathrm{J} \mathrm{Am}$ Acad Dermatol. 1994;31(3 Pt 1):513-514.

40. Handrick C, Alster TS. Laser treatment of atrophoderma vermiculata. J Am Acad Dermatol. 2001;44(4):693-695.

41. Tanzi E, Alster TS. Pulsed dye laser treatment of multiple eccrine hidrocystomas: a novel approach. Dermatol Surg. 2001;27(10):898-900.

42. Cliff S, Felix RH, Singh L, Harland CC. The successful treatment of lupus pernio with the flashlamp pulsed dye laser. J Cutan Laser Ther. 1999;1(1):49-52.

43. Raulin C, Schmidt C, Hellwig S. Cutaneous lupus erythematosus-treatment with pulsed dye laser. Br J Dermatol. 1999;141(6):1046-1050.

44. Eisen D, Alster TS. Use of a $585 \mathrm{~nm}$ pulsed dye laser for the treatment of morphea. Dermatol Surg. 2002;28(7):615-616.

45. Welsh JH, Schroeder TL, Levy ML. Granuloma faciale in a child successfully treated with the pulsed dye laser. J Am Acad Dermatol. 1999;41(2 Pt 2):351-353.

46. Currie CL, Monk BE. Pulsed dye laser treatment of necrobiosis lipoidica: report of a case. J Cutan Laser Ther. 1999;1(4):239-241.

47. Kaufman AJ. Treatment of elastosis perforans serpiginosa with the flashlamp pulsed dye laser. Dermatol Surg. 2000;26(11):1060-1062.

48. Schonermark MP, Schmidt C, Raulin C. Treatment of sebaceous gland hyperplasia with the pulsed dye laser. Lasers Surg Med. 1997;21(4): 313-316.

49. Hughes PS. Treatment of molluscum contagiosum with the $585-\mathrm{nm}$ pulsed dye laser. Dermatol Surg. 1998;24(2):229-230.

50. Goldman MP. Treatment of benign vascular lesions with the Photoderm VL high-intensity pulsed light source. Adv Dermatol. 1997;13:503-521.

51. Raulin C, Schroeter CA, Weiss RA, Keiner M, Werner S. Treatment of port-wine stains with a noncoherent pulsed light source: a retrospective study. Arch Dermatol. 1999;135(6):679-683.

52. Jay H, Borek C. Treatment of a venous-lake angioma with intense pulsed light. Lancet. 1998;351(9096):112.

53. Weiss MA, Hsu JT, Neuhaus I, Sadick NS, Duffy DM. Consensus for sclerotherapy. Dermatol Surg. 2014;40(12):1309-1318.

54. Weiss RA, Dover JS. Laser surgery of leg veins. Dermatol Clin. 2002;20(1):19-36

55. Reichert D. Evaluation of the long-pulse dye laser for the treatment of leg telangiectasias. Dermatol Surg. 1998;24(7):737-740.

56. Raulin C, Weiss RA, Schonermark MP. Treatment of essential telangiectasias with an intense pulsed light source (PhotoDerm VL). Dermatol Surg. 1997;23(10):941-945; discussion 945-946.

57. Meesters AA, Pitassi LH, Campos V, Wolkerstorfer A, Dierickx CC. Transcutaneous laser treatment of leg veins. Lasers Med Sci. 2014; 29(2):481-492.

58. McDaniel DH, Ash K, Lord J, Newman J, Adrian RM, Zukowski M. Laser therapy of spider leg veins: clinical evaluation of a new long pulsed alexandrite laser. Dermatol Surg. 1999;25(1):52-58.

59. Kauvar AN, Lou WW. Pulsed alexandrite laser for the treatment of leg telangiectasia and reticular veins. Arch Dermatol. 2000;136(11): 1371-1375.

60. Alster T, Zaulyanov L. Laser scar revision: a review. Dermatol Surg. 2007;33(2):131-140.

61. Sobanko JF, Alster TS. Laser treatment for improvement and minimization of facial scars. Facial Plast Surg Clin North Am. 2011;19(3):527-542.

62. Sobanko JF, Alster TS. Management of acne scarring, part I: a comparative review of laser surgical approaches. Am J Clin Dermatol. 2012;13(5):319-330.

63. Alster TS, Handrick C. Laser treatment of hypertrophic scars, keloids, and striae. Semin Cutan Med Surg. 2000;19(4):287-292.

64. Manuskiatti W, Fitzpatrick RE, Goldman MP. Energy density and numbers of treatment affect response of keloidal and hypertrophic sternotomy scars to the 585-nm flashlamp-pumped pulsed-dye laser. J Am Acad Dermatol. 2001;45(4):557-565. 
65. Manuskiatti W, Fitzpatrick RE. Treatment response of keloidal and hypertrophic sternotomy scars: comparison among intralesional corticosteroid, 5-fluorouracil, and 585-nm flashlamp-pumped pulseddye laser treatments. Arch Dermatol. 2002;138(9):1149-1155.

66. Alster T. Laser scar revision: comparison study of 585-nm pulsed dye laser with and without intralesional corticosteroids. Dermatol Surg. 2003;29(1):25-29.

67. Waibel JS, Wulkan AJ, Shumaker PR. Treatment of hypertrophic scars using laser and laser assisted corticosteroid delivery. Lasers Surg Med. 2013;45(3):135-140.

68. Anderson RR, Donelan MB, Hivnor C, et al. Laser treatment of traumatic scars with an emphasis on ablative fractional laser resurfacing: consensus report. JAMA Dermatol. 2014;150(2):187-193.

69. Malekzad F, Shakoei S, Ayatollahi A, Hejazi S. The safety and efficacy of the $1540 \mathrm{~nm}$ non-ablative fractional XD probe of star lux 500 device in the treatment of striae alba: before-after study. $J$ Lasers Med Sci. 2014;5(4):194-198.

70. Tretti Clementoni M, Lavagno R. A novel $1565 \mathrm{~nm}$ non-ablative fractional device for stretch marks: a preliminary report. J Cosmet Laser Ther. 2015;17(3):148-155.

71. Murphy GF, Shepard RS, Paul BS, Menkes A, Anderson RR, Parrish JA. Organelle-specific injury to melanin-containing cells in human skin by pulsed laser irradiation. Lab Invest. 1983;49(6):680-685.

72. Arndt KA. Argon laser treatment of lentigo maligna. JAm Acad Dermatol. 1984;10(6):953-957.

73. Chan HH, Fung WK, Ying SY, Kono T. An in vivo trial comparing the use of different types of $532 \mathrm{~nm} \mathrm{Nd}$ :YAG lasers in the treatment of facial lentigines in Oriental patients. Dermatol Surg. 2000;26(8):743-749.

74. Bailin PL, Ratz JL, Levine HL. Removal of tattoos by $\mathrm{CO}_{2}$ laser. J Dermatol Surg Oncol. 1980;6(12):997-1001.

75. Reid WH, Miller ID, Murphy MJ, Paul JP, Evans JH. Q-switched ruby laser treatment of tattoos; a 9-year experience. Br J Plast Surg. 1990;43(6):663-669.

76. Scheibner A, Kenny G, White W, Wheeland RG. A superior method of tattoo removal using the Q-switched ruby laser. J Dermatol Surg Oncol. 1990;16(12):1091-1098.

77. Ashinoff R, Geronemus RG. Rapid response of traumatic and medical tattoos to treatment with the Q-switched ruby laser. Plast Reconstr Surg. 1993;91(5):841-845.

78. Achauer BM, Nelson JS, Vander Kam VM, Applebaum R. Treatment of traumatic tattoos by Q-switched ruby laser. Plast Reconstr Surg. 1994;93(2):318-323.

79. Goldberg DJ, Stampien T. Q-switched ruby laser treatment of congenital nevi. Arch Dermatol. 1995;131(5):621-623.

80. Nehal KS, Levine VJ, Ashinoff R. The treatment of benign pigmented lesions and tattoos with the Q-switched ruby laser. A comparative study using the 5.0- and 6.5-mm spot size. Dermatol Surg. 1996;22(8): 683-686.

81. Raulin C, Schonermark MP, Greve B, Werner S. Q-switched ruby laser treatment of tattoos and benign pigmented skin lesions: a critical review. Ann Plast Surg. 1998;41(5):555-565.

82. Ono I, Tateshita T. Efficacy of the ruby laser in the treatment of Ota's nevus previously treated using other therapeutic modalities. Plast Reconstr Surg. 1998;102(7):2352-2357.

83. Grevelink JM, Duke D, van Leeuwen RL, Gonzalez E, DeCoste SD, Anderson RR. Laser treatment of tattoos in darkly pigmented patients: efficacy and side effects. J Am Acad Dermatol. 1996;34(4): 653-656.

84. Kono T, Nozaki M, Chan HH, Mikashima Y. A retrospective study looking at the long-term complications of Q-switched ruby laser in the treatment of nevus of Ota. Lasers Surg Med. 2001;29(2):156-159.

85. Kilmer SL. Laser eradication of pigmented lesions and tattoos. Dermatol Clin. 2002;20(1):37-53.

86. Fitzpatrick RE, Goldman MP. Tattoo removal using the alexandrite laser. Arch Dermatol. 1994;130(12):1508-1514.

87. Alster TS. Q-switched alexandrite laser treatment $(755 \mathrm{~nm})$ of professional and amateur tattoos. J Am Acad Dermatol. 1995;33(1):69-73.
88. Stafford TJ, Lizek R, Boll J, Tan OT. Removal of colored tattoos with the Q-switched alexandrite laser. Plast Reconstr Surg. 1995;95(2): 313-320.

89. Leuenberger ML, Mulas MW, Hata TR, Goldman MP, Fitzpatrick RE, Grevelink JM. Comparison of the Q-switched alexandrite, Nd:YAG, and ruby lasers in treating blue-black tattoos. Dermatol Surg. 1999;25(1):10-14.

90. Lam AY, Wong DS, Lam LK, Ho WS, Chan HH. A retrospective study on the efficacy and complications of Q-switched alexandrite laser in the treatment of acquired bilateral nevus of Ota-like macules. Dermatol Surg. 2001;27(11):937-941; discussion 941-942.

91. Green D, Friedman KJ. Treatment of minocycline-induced cutaneous pigmentation with the Q-switched Alexandrite laser and a review of the literature. J Am Acad Dermatol. 2001;44(2 Suppl): 342-347.

92. Jang KA, Chung EC, Choi JH, Sung KJ, Moon KC, Koh JK. Successful removal of freckles in Asian skin with a Q-switched alexandrite laser. Dermatol Surg. 2000;26(3):231-234.

93. Alster TS, Williams CM. Treatment of nevus of Ota by the Q-switched alexandrite laser. Dermatol Surg. 1995;21(7):592-596.

94. Alster TS, Gupta SN. Minocycline-induced hyperpigmentation treated with a 755-nm Q-switched alexandrite laser. Dermatol Surg. 2004;30(9):1201-1204.

95. Kilmer SL, Lee MS, Grevelink JM, Flotte TJ, Anderson RR. The Q-switched Nd:YAG laser effectively treats tattoos. A controlled, dose-response study. Arch Dermatol. 1993;129(8):971-978.

96. Tse Y, Levine VJ, McClain SA, Ashinoff R. The removal of cutaneous pigmented lesions with the Q-switched ruby laser and the Q-switched neodymium: yttrium-aluminum-garnet laser. A comparative study. J Dermatol Surg Oncol. 1994;20(12):795-800.

97. Kilmer SL, Wheeland RG, Goldberg DJ, Anderson RR. Treatment of epidermal pigmented lesions with the frequency-doubled Q-switched Nd:YAG laser. A controlled, single-impact, dose-response, multicenter trial. Arch Dermatol. 1994;130(12):1515-1519.

98. Ferguson JE, August PJ. Evaluation of the $\mathrm{Nd} / \mathrm{YAG}$ laser for treatment of amateur and professional tattoos. Br J Dermatol. 1996;135(4): 586-591.

99. Jones A, Roddey P, Orengo I, Rosen T. The Q-switched ND:YAG laser effectively treats tattoos in darkly pigmented skin. Dermatol Surg. 1996;22(12):999-1001.

100. Troilius AM. Effective treatment of traumatic tattoos with a Q-switched Nd:YAG laser. Lasers Surg Med. 1998;22(2):103-108.

101. Freedman JR, Kaufman J, Metelitsa AI, Green JB. Picosecond lasers: the next generation of short-pulsed lasers. Semin Cutan Med Surg. 2014;33(4):164-168.

102. Haedersdal M, Bech-Thomsen N, Wulf HC. Skin reflectance-guided laser selections for treatment of decorative tattoos. Arch Dermatol. 1996;132(4):403-407.

103. Anderson RR, Geronemus R, Kilmer SL, Farinelli W, Fitzpatrick RE. Cosmetic tattoo ink darkening. A complication of Q-switched and pulsed-laser treatment. Arch Dermatol. 1993;129(8):1010-1014.

104. Ashinoff R, Levine VJ, Soter NA. Allergic reactions to tattoo pigment after laser treatment. Dermatol Surg. 1995;21(4):291-294.

105. Taylor CR. Laser ignition of traumatically embedded firework debris. Lasers Surg Med. 1998;22(3):157-158.

106. Bjerring $\mathrm{P}$, Christiansen $\mathrm{K}$. Intense pulsed light source for treatment of small melanocytic nevi and solar lentigines. J Cutan Laser Ther. 2000;2(4):177-181.

107. Kawada A, Shiraishi H, Asai M, et al. Clinical improvement of solar lentigines and ephelides with an intense pulsed light source. Dermatol Surg. 2002;28(6):504-508.

108. Sasaya H, Kawada A, Wada T, Hirao A, Oiso N. Clinical effectiveness of intense pulsed light therapy for solar lentigines of the hands. Dermatol Ther. 2011;24(6):584-586.

109. Lask G, Elman M, Slatkine M, Waldman A, Rozenberg Z. Laserassisted hair removal by selective photothermolysis. Preliminary results. Dermatol Surg. 1997;23(9):737-739. 
110. Nanni CA, Alster TS. A practical review of laser-assisted hair removal using the Q-switched Nd:YAG, long-pulsed ruby, and long-pulsed alexandrite lasers. Dermatol Surg. 1998;24(12):1399-1405; discussion 1405.

111. Dierickx CC. Hair removal by lasers and intense pulsed light sources. Dermatol Clin. 2002;20(1):135-146.

112. Altshuler GB, Anderson RR, Manstein D, Zenzie HH, Smirnov MZ. Extended theory of selective photothermolysis. Lasers Surg Med. 2001;29(5):416-432.

113. Rogachefsky AS, Silapunt S, Goldberg DJ. Evaluation of a new super-long-pulsed $810 \mathrm{~nm}$ diode laser for the removal of unwanted hair: the concept of thermal damage time. Dermatol Surg. 2002;28(5): 410-414.

114. Grossman MC, Dierickx C, Farinelli W, Flotte T, Anderson RR. Damage to hair follicles by normal-mode ruby laser pulses. J Am Acad Dermatol. 1996;35(6):889-894.

115. Dierickx CC, Grossman MC, Farinelli WA, Anderson RR. Permanent hair removal by normal-mode ruby laser. Arch Dermatol. 1998;134(7):837-842.

116. McDaniel DH, Lord J, Ash K, Newman J, Zukowski M. Laser hair removal: a review and report on the use of the long-pulsed alexandrite laser for hair reduction of the upper lip, leg, back, and bikini region. Dermatol Surg. 1999;25(6):425-430.

117. Nanni CA, Alster TS. Laser-assisted hair removal: side effects of Q-switched Nd:YAG, long-pulsed ruby, and alexandrite lasers. J Am Acad Dermatol. 1999;41(2 Pt 1):165-171.

118. Garcia C, Alamoudi H, Nakib M, Zimmo S. Alexandrite laser hair removal is safe for Fitzpatrick skin types IV-VI. Dermatol Surg 2000;26(2):130-134.

119. Eremia S, Li CY, Umar SH, Newman N. Laser hair removal: long-term results with a $755 \mathrm{~nm}$ alexandrite laser. Dermatol Surg. 2001;27(11): 920-924.

120. Handrick C, Alster TS. Comparison of long-pulsed diode and longpulsed alexandrite lasers for hair removal: a long-term clinical and histologic study. Dermatol Surg. 2001;27(7):622-626.

121. Campos VB, Dierickx CC, Farinelli WA, Lin TY, Manuskiatti W, Anderson RR. Hair removal with an 800-nm pulsed diode laser. $J$ Am Acad Dermatol. 2000;43(3):442-447.

122. Lou WW, Quintana AT, Geronemus RG, Grossman MC. Prospective study of hair reduction by diode laser $(800 \mathrm{~nm})$ with long-term follow-up. Dermatol Surg. 2000;26(5):428-432.

123. Goldberg DJ, Silapunt S. Hair removal using a long-pulsed Nd:YAG laser: comparison at fluences of 50,80, and $100 \mathrm{~J} / \mathrm{cm}$. Dermatol Surg. 2001;27(5):434-436.

124. Lorenz S, Brunnberg S, Landthaler M, Hohenleutner U. Hair removal with the long pulsed Nd:YAG laser: a prospective study with one year follow-up. Lasers Surg Med. 2002;30(2):127-134.

125. Weiss RA, Weiss MA, Marwaha S, Harrington AC. Hair removal with a non-coherent filtered flashlamp intense pulsed light source. Lasers Surg Med. 1999;24(2):128-132.

126. Sadick NS, Weiss RA, Shea CR, Nagel H, Nicholson J, Prieto VG Long-term photoepilation using a broad-spectrum intense pulsed light source. Arch Dermatol. 2000;136(11):1336-1340.

127. Alster TS, Bryan H, Williams CM. Long-pulsed Nd:YAG laser-assisted hair removal in pigmented skin: a clinical and histological evaluation. Arch Dermatol. 2001;137(7):885-889.

128. Tanzi EL, Alster TS. Long-pulsed 1064-nm Nd:YAG laser-assisted hair removal in all skin types. Dermatol Surg. 2004;30(1):13-17.

129. Chan CS, Dover JS. Nd:YAG laser hair removal in Fitzpatrick skin types IV to VI. J Drugs Dermatol. 2013;12(3):366-367.

130. Aslam A, Alster TS. Evolution of laser skin resurfacing: from scanning to fractional technology. Dermatol Surg. 2014;40(11):1163-1172.

131. Waldorf HA, Kauvar AN, Geronemus RG. Skin resurfacing of fine to deep rhytides using a char-free carbon dioxide laser in 47 patients. Dermatol Surg. 1995;21(11):940-946.

132. Lowe NJ, Lask G, Griffin ME, Maxwell A, Lowe P, Quilada F. Skin resurfacing with the ultrapulse carbon dioxide laser. Observations on 100 patients. Dermatol Surg. 1995;21(12):1025-1029.
133. Fitzpatrick RE, Goldman MP, Satur NM, Tope WD. Pulsed carbon dioxide laser resurfacing of photo-aged facial skin. Arch Dermatol. 1996;132(4):395-402.

134. Alster TS, Garg S. Treatment of facial rhytides with a high-energy pulsed carbon dioxide laser. Plast Reconstr Surg. 1996;98(5):791-794.

135. Ross EV, Miller C, Meehan K, et al. One-pass $\mathrm{CO}_{2}$ versus multiplepass Er:YAG laser resurfacing in the treatment of rhytides: a comparison side-by-side study of pulsed $\mathrm{CO}_{2}$ and Er:YAG lasers. Dermatol Surg. 2001;27(8):709-715.

136. Rostan EF, Fitzpatrick RE, Goldman MP. Laser resurfacing with a long pulse erbium:YAG laser compared to the $950 \mathrm{~ms}$ pulsed $\mathrm{CO}(2)$ laser. Lasers Surg Med. 2001;29(2):136-141.

137. Alster TS, Nanni CA, Williams CM. Comparison of four carbon dioxide resurfacing lasers. A clinical and histopathologic evaluation. Dermatol Surg. 1999;25(3):153-158; discussion 159.

138. Alster TS. Cutaneous resurfacing with $\mathrm{CO}_{2}$ and erbium: YAG lasers: preoperative, intraoperative, and postoperative considerations. Plast Reconstr Surg. 1999;103(2):619-632; discussion 633-634.

139. Alster TS, West TB. Resurfacing of atrophic facial acne scars with a high-energy, pulsed carbon dioxide laser. Dermatol Surg. 1996;22(2):151-154; discussion 154-155.

140. Walia S, Alster TS. Prolonged clinical and histologic effects from $\mathrm{CO}_{2}$ laser resurfacing of atrophic acne scars. Dermatol Surg. 1999;25(12):926-930.

141. Fitzpatrick RE, Rostan EF, Marchell N. Collagen tightening induced by carbon dioxide laser versus erbium: YAG laser. Lasers Surg Med. 2000;27(5):395-403.

142. Alster TS, Bellew SG. Improvement of dermatochalasis and periorbital rhytides with a high-energy pulsed $\mathrm{CO}_{2}$ laser: a retrospective study. Dermatol Surg. 2004;30(4 Pt 1):483-487; discussion 487.

143. Wollina U. Ablative erbium:YAG laser treatment of idiopathic chronic inflammatory non-cicatricial balanoposthitis (Zoon's disease) - a series of 20 patients with long-term outcome. J Cosmet Laser Ther. 2010;12(3):120-123

144. Albertini JG, Holck DE, Farley MF. Zoon's balanitis treated with Erbium:YAG laser ablation. Lasers Surg Med. 2002;30(2):123-126.

145. Omi T, Numano K. The role of the $\mathrm{CO}_{2}$ laser and fractional $\mathrm{CO}_{2}$ laser in dermatology. Laser Therapy. 2014;23(1):49-60.

146. Tanzi EL, Alster TS. Single-pass carbon dioxide versus multiple-pass Er:YAG laser skin resurfacing: a comparison of postoperative wound healing and side-effect rates. Dermatol Surg. 2003;29(1):80-84.

147. Bernstein LJ, Kauvar AN, Grossman MC, Geronemus RG. The short- and long-term side effects of carbon dioxide laser resurfacing. Dermatol Surg. 1997;23(7):519-525.

148. Nanni CA, Alster TS. Complications of carbon dioxide laser resurfacing. An evaluation of 500 patients. Dermatol Surg. 1998;24(3): 315-320

149. Sriprachya-Anunt S, Fitzpatrick RE, Goldman MP, Smith SR. Infections complicating pulsed carbon dioxide laser resurfacing for photoaged facial skin. Dermatol Surg. 1997;23(7):527-535; discussion 535-536.

150. Tanzi EL, Alster TS. Side effects and complications of variable-pulsed erbium:yttrium-aluminum-garnet laser skin resurfacing: extended experience with 50 patients. Plast Reconstr Surg. 2003;111(4): 1524-1529; discussion 1530-1532.

151. Alster TS, Lupton JR. Prevention and treatment of side effects and complications of cutaneous laser resurfacing. Plast Reconstr Surg. 2002;109(1):308-316; discussion 317-318.

152. Goldberg DJ, Whitworth J. Laser skin resurfacing with the Q-switched Nd:YAG laser. Dermatol Surg. 1997;23(10):903-906; discussion 906-907.

153. Kim YJ, Lee HS, Son SW, Kim SN, Kye YC. Analysis of hyperpigmentation and hypopigmentation after Er:YAG laser skin resurfacing Lasers Surg Med. 2005;36(1):47-51.

154. Lupton JR, Williams CM, Alster TS. Nonablative laser skin resurfacing using a $1540 \mathrm{~nm}$ erbium glass laser: a clinical and histologic analysis. Dermatol Surg. 2002;28(9):833-835. 
155. Tanzi EL, Williams CM, Alster TS. Treatment of facial rhytides with a nonablative 1,450-nm diode laser: a controlled clinical and histologic study. Dermatol Surg. 2003;29(2):124-128.

156. Tanzi EL, Alster TS. Comparison of a 1450-nm diode laser and a 1320-nm Nd:YAG laser in the treatment of atrophic facial scars: a prospective clinical and histologic study. Dermatol Surg. 2004; 30(2 Pt 1):152-157.

157. Doshi SN, Alster TS. $1,450 \mathrm{~nm}$ long-pulsed diode laser for nonablative skin rejuvenation. Dermatol Surg. 2005;31(9 Pt 2):1223-1226; discussion 1226 .

158. Manstein D, Herron GS, Sink RK, Tanner H, Anderson RR. Fractional photothermolysis: a new concept for cutaneous remodeling using microscopic patterns of thermal injury. Lasers Surg Med. 2004;34(5):426-438.

159. Hantash BM, Bedi VP, Kapadia B, et al. In vivo histological evaluation of a novel ablative fractional resurfacing device. Lasers Surg Med. 2007;39(2):96-107.

160. Hantash BM, Mahmood MB. Fractional photothermolysis: a novel aesthetic laser surgery modality. Dermatol Surg. 2007;33(5):525-534.

161. Alster TS, Tanzi EL, Lazarus M. The use of fractional laser photothermolysis for the treatment of atrophic scars. Dermatol Surg. 2007;33(3):295-299.

162. Chrastil B, Glaich AS, Goldberg LH, Friedman PM. Second-generation 1,550-nm fractional photothermolysis for the treatment of acne scars. Dermatol Surg. 2008;34(10):1327-1332.

163. Hu S, Chen MC, Lee MC, Yang LC, Keoprasom N. Fractional resurfacing for the treatment of atrophic facial acne scars in Asian skin. Dermatol Surg. 2009;35(5):826-832.

164. Wanner M, Tanzi EL, Alster TS. Fractional photothermolysis: treatment of facial and nonfacial cutaneous photodamage with a 1,550-nm erbium-doped fiber laser. Dermatol Surg. 2007;33(1): 23-28.

165. Kunishige JH, Katz TM, Goldberg LH, Friedman PM. Fractional photothermolysis for the treatment of surgical scars. Dermatol Surg. 2010;36(4):538-541.

166. Lin JY, Warger WC, Izikson L, Anderson RR, Tannous Z. A prospective, randomized controlled trial on the efficacy of fractional photothermolysis on scar remodeling. Lasers Surg Med. 2011;43(4): 265-272.

167. Waibel J, Wulkan AJ, Lupo M, Beer K, Anderson RR. Treatment of burn scars with the $1,550 \mathrm{~nm}$ nonablative fractional Erbium laser. Lasers Surg Med. 2012;44(6):441-446.

168. Saedi N, Petrell K, Arndt K, Dover J. Evaluating facial pores and skin texture after low-energy nonablative fractional 1440-nm laser treatments. J Am Acad Dermatol. 2013;68(1):113-118.

169. Katz TM, Glaich AS, Goldberg LH, Firoz BF, Dai T, Friedman PM. Treatment of melasma using fractional photothermolysis: a report of eight cases with long-term follow-up. Dermatol Surg. 2010;36(8): 1273-1280.

170. Lee HM, Haw S, Kim JK, Chang SE, Lee MW. Split-face study using a 1,927-nm thulium fiber fractional laser to treat photoaging and melasma in Asian skin. Dermatol Surg. 2013;39(6):879-888.

171. Jih MH, Goldberg LH, Kimyai-Asadi A. Fractional photothermolysis for photoaging of hands. Dermatol Surg. 2008;34(1):73-78.
172. Jung JY, Lee JH, Ryu DJ, Lee SJ, Bang D, Cho SB. Lower-fluence, higher-density versus higher-fluence, lower-density treatment with a 10,600-nm carbon dioxide fractional laser system: a split-face, evaluator-blinded study. Dermatol Surg. 2010;36(12):2022-2029.

173. Tierney EP, Hanke CW. Fractionated carbon dioxide laser treatment of photoaging: prospective study in 45 patients and review of the literature. Dermatol Surg. 2011;37(9):1279-1290.

174. Tierney EP. Treatment of acne scarring using a dual-spot-size ablative fractionated carbon dioxide laser: review of the literature. Dermatol Surg. 2011;37(7):945-961.

175. Hedelund L, Haak CS, Togsverd-Bo K, Bogh MK, Bjerring P, Haedersdal M. Fractional $\mathrm{CO}_{2}$ laser resurfacing for atrophic acne scars: a randomized controlled trial with blinded response evaluation. Lasers Surg Med. 2012;44(6):447-452.

176. Graber EM, Tanzi EL, Alster TS. Side effects and complications of fractional laser photothermolysis: experience with 961 treatments. Dermatol Surg. 2008;34(3):301-305; discussion 305-307.

177. Metelitsa AI, Alster TS. Fractionated laser skin resurfacing treatment complications: a review. Dermatol Surg. 2010;36(3):299-306.

178. Alster TS, Wanitphakdeedecha R. Improvement of postfractional laser erythema with light-emitting diode photomodulation. Dermatol Surg. 2009;35(5):813-815.

179. Chan HH, Manstein D, Yu CS, Shek S, Kono T, Wei WI. The prevalence and risk factors of post-inflammatory hyperpigmentation after fractional resurfacing in Asians. Lasers Surg Med. 2007;39(5): 381-385

180. Tan KL, Kurniawati C, Gold MH. Low risk of postinflammatory hyperpigmentation in skin types 4 and 5 after treatment with fractional $\mathrm{CO}_{2}$ laser device. J Drugs Dermatol. 2008;7(8):774-777.

181. Fife DJ, Fitzpatrick RE, Zachary CB. Complications of fractional $\mathrm{CO}_{2}$ laser resurfacing: four cases. Lasers Surg Med. 2009;41(3): 179-184.

182. Avram MM, Tope WD, Yu T, Szachowicz E, Nelson JS. Hypertrophic scarring of the neck following ablative fractional carbon dioxide laser resurfacing. Lasers Surg Med. 2009;41(3):185-188.

183. Asawanonda P, Anderson RR, Chang Y, Taylor CR. 308-nm excimer laser for the treatment of psoriasis: a dose-response study. Arch Dermatol. 2000;136(5):619-624.

184. Feldman SR, Mellen BG, Housman TS, et al. Efficacy of the 308-nm excimer laser for treatment of psoriasis: results of a multicenter study. J Am Acad Dermatol. 2002;46(6):900-906.

185. Mafong EA, Friedman PM, Kauvar AN, Bernstein LJ, AlexiadesArmenakas M, Geronemus RG. Treatment of inverse psoriasis with the $308 \mathrm{~nm}$ excimer laser. Dermatol Surg. 2002;28(6):530-532.

186. Trehan M, Taylor CR. High-dose 308-nm excimer laser for the treatment of psoriasis. J Am Acad Dermatol. 2002;46(5):732-737.

187. Spencer JM, Nossa R, Ajmeri J. Treatment of vitiligo with the 308-nm excimer laser: a pilot study. J Am Acad Dermatol. 2002;46(5): $727-731$

188. Sun Y, Wu Y, Xiao B, et al. Treatment of 308-nm excimer laser on vitiligo: a systemic review of randomized controlled trials. J Dermatolog Treat. 2015:1-7.

189. Mehraban S, Feily A. 308nm excimer laser in dermatology. J Lasers Med Sci. 2014;5(1):8-12.
Clinical, Cosmetic and Investigational Dermatology

\section{Publish your work in this journal}

Clinical, Cosmetic and Investigational Dermatology is an international, peer-reviewed, open access, online journal that focuses on the latest clinical and experimental research in all aspects of skin disease and cosmetic interventions. All areas of dermatology will be covered; contributions will be welcomed from all clinicians and

\section{Dovepress}

basic science researchers globally. This journal is indexed on CAS. The manuscript management system is completely online and includes a very quick and fair peer-review system, which is all easy to use. Visit http://www.dovepress.com/testimonials.php to read real quotes from published authors. 